\title{
Managing glyphosate-resistant common ragweed (Ambrosia artemisiifolia): effect of glyphosate-phenoxy tank mixes on growth, fecundity, and seed viability
}

\author{
Jichul Bae, Robert E. Nurse, Marie-Josée Simard, and Eric R. Page*
}

Common ragweed is one of the most important weeds in the soybean-producing areas of the United States and Canada. Recently, glyphosate-resistant (GR) biotypes have been reported in 15 states and one Canadian province. Reducing the proliferation of GR common ragweed biotypes is complicated by the high fecundity and complex seed germination behavior exhibited by this species. An experiment was conducted to evaluate the efficacy of late herbicide applications for reducing seed production, seed weight, and seed viability of a GR common ragweed biotype. Herbicide treatments included: water control, glyphosate, 2,4-D, dicamba, 2,4-D plus glyphosate, and dicamba plus glyphosate. Treatments were applied at the appearance of male flower buds (Biologische Bundesanstalt, Bundessortenamt and Chemical industry scale $[\mathrm{BBCH}] 51$ ) or at the early female flowering stage (BBCH 61 to 63). At BBCH 51, 2,4-D or dicamba applied alone or in a tank mix with glyphosate reduced seed production by an average of $80 \%$. Conversely, seed production following these same treatments applied at BBCH 61 to 63 was not significantly different from when glyphosate was applied alone. At this stage of development, all herbicide treatments reduced seed viability relative to the control; however, treatments containing 2,4-D or dicamba resulted in significantly lower viability than when glyphosate was applied alone. These results suggest that the application of tank mixes containing 2,4-D or dicamba have the potential to limit seed production of GR common ragweed when applied on or before BBCH 51. The development of new technologies that facilitate the in-crop application of tank mixes containing 2,4-D or dicamba may therefore be an effective option for limiting population establishment, seedbank replenishment, and future spread of glyphosate-resistant alleles.

Nomenclature: 2,4-D, dicamba, glyphosate, common ragweed, soybean, Ambrosia artemisiifolia L. Key words: 100 -seed weight, phenoxy herbicides, seed production, seed viability.

Common ragweed is one of the most important weeds in the soybean-producing areas of the United States and Canada (Coble et al. 1981; Ontario Ministry of Agriculture, Food and Rural Affairs [OMAFRA] 2015; Shurtleff and Coble 1985; Weaver 2001). For example, Shurtleff and Coble (1985) found that common ragweed at densities of 16 plants per $10 \mathrm{~m}$ row reduced soybean yield by up to $12 \%$ in North Carolina. Coble et al. (1981) estimated soybean yield losses of $33 \mathrm{~kg} \mathrm{ha}^{-1}$ when only a single common ragweed plant occurred per $10 \mathrm{~m}$ row in North Carolina. In Ontario, Canada, it has been reported that a single common ragweed

\footnotetext{
DOI: 10.1614/WS-D-16-00094.1

*First, second, and fourth authors: Postdoctoral Fellow, Research Scientist, and Research Scientist, Harrow Research and Development Centre, Agriculture and Agri-Food Canada, 2585 County Road 20, Harrow, Ontario, N8H 4W7, Canada; third author: Research Scientist, Saint-Jean-sur-Richelieu Research and Development Centre, 430 Gouin Boulevard, Saint-Jean-surRichelieu, Québec, J3B 3E6, Canada. Corresponding author's E-mail: eric.page@agr.gc.ca
}

plant per square meter reduces soybean yield by up to $10 \%$ and that five plants per square meter can result in up to $33 \%$ yield loss (Cowbrough et al. 2003; OMAFRA 2009).

Nearly $50 \%$ of soybean hectares in the United States and Ontario, Canada, are maintained as no-till (Soil Conservation Council of Canada 2015; Wade et al. 2015). The increase in no-till soybeans has increased the reliance on in-crop applications of glyphosate (Young 2006). The introduction of glyphosate-resistant (GR) soybean cultivars has provided growers with several advantages, including improved and more consistent weed control, decreased herbicide application costs, and reduced time and labor inputs (Beckie et al. 2006; Young 2006). In 2012 GR soybean comprised about 93 and $79 \%$ of soybean crop areas in the United States and Canada, respectively (Beckie et al. 2014; Bøhn et al. 2014). However, weed management in GR cropping systems has been complicated by the development and spread of GR weed biotypes. Glyphosate resistant common ragweed has been

Bae et al.: Late herbicide application • 
confirmed in 15 U.S. states: Arkansas (2004), Missouri (2004), Kentucky (2006), North Carolina (2006), Ohio (2006), Indiana (2007), Kansas (2007), North Dakota (2007), South Dakota (2007), Pennsylvania (2008), Minnesota (2008), Alabama (2013), New Jersey (2013), Nebraska (2013) and Mississippi (2014) (Heap 2015). In Canada, the first and only case of GR common ragweed to date was discovered in a soybean field in southern Ontario in 2012 (Heap 2015; Van Wely et al. 2015).

The high fecundity and complex seed germination behavior of common ragweed, resulting from primary and secondary dormancy, contributes to its success in establishing and maintaining a persistent seedbank in arable land (Baskin and Baskin 1980; Bazzaz 1974; Dickerson and Sweet 1971). A single common ragweed plant can produce between 3,185 and 62,000 seeds, depending on plant size (Bazzaz 1974; Dickerson and Sweet 1971). In a soybean crop, ragweed plants emerging 1 mo after the crop produced up to 2,914 seeds per plant (Simard and Benoit 2012). Once in the seedbank, these seeds can remain viable for $39 \mathrm{yr}$ (Baskin and Baskin 1980). Therefore, seed production by GR common ragweed individuals that escape herbicide control can provide seedbank replenishment and could promote the subsequent spread of resistant alleles.

The use of a late herbicide application has been advocated as a strategy for reducing weed seed production and viability (Clay and Griffin 2000; Crow et al. 2015; Gauvrit and Chauvel 2010; Hill et al. 2016; Jha and Norsworthy 2012; Kumar and Jha 2015; Nurse et al. 2015; Steadman et al. 2006; Taylor and Oliver 1997; Walker and Oliver 2008). Jha and Norsworthy (2012) demonstrated that application of glufosinate, 2,4-D, or dicamba at the first appearance of an inflorescence reduced seed production and viability of GR Palmer amaranth (Amaranthus palmeri S. Wats.). However, up to now, late application options for the control of GR biotypes in crop have been limited because of crop injury risks associated with applying an efficacious herbicide at growth stages when the crop is less tolerant to these herbicides. The development and release of new Group 4-tolerant crop hybrids and varieties offers a potential mechanism to address this issue. Monsanto's dicamba-tolerant technology (i.e., Xtend $^{\mathrm{TM}}$ ) and Dow Agroscience's 2,4-D-tolerant technology (i.e., Enlist ${ }^{\mathrm{PM}}$ ) are anticipated to be released into the U.S. and Canadian markets shortly. While Group 4, phenoxy herbicides have shown good efficacy for controlling common ragweed at early growth stages (OMAFRA 2015; Payne et al.
2010), no information is currently available on how effective these herbicides or a tank mix of these herbicides with glyphosate might be at reducing the number and viability of GR common ragweed seeds when applied to ragweed plants at or near flowering. Therefore, the objective of the following study was to evaluate the effect of late herbicide application on growth, seed production, and seed viability of GR common ragweed.

\section{Materials and Methods}

Growth chamber and germination cabinet experiments were conducted and repeated at the Harrow Research and Development Centre, Agriculture and Agri-Food Canada, Harrow, Ontario, Canada. A randomized complete block factorial design with three replicates and two experimental runs was used to evaluate the efficacy of late herbicide application on the growth, fecundity, and seed viability of GR common ragweed. Tested factors included herbicide treatment and growth stage of common ragweed. The six herbicide treatments included: (1) a water control, (2) glyphosate ( $900 \mathrm{~g}$ ae ha $\left.{ }^{-1}\right)$, (3) 2,4-D (733 g ae ha-1), (4) dicamba (384g ae ha $\mathrm{g}^{-1}$ ), (5) 2,4-D plus glyphosate $\left(733 \mathrm{~g}^{\mathrm{ae} \mathrm{h}} \mathrm{ha}^{-1}+900 \mathrm{~g}\right.$ ae $\left.\mathrm{ha}^{-1}\right)$, and (6) dicamba plus glyphosate $(384 \mathrm{~g}$ ae $\mathrm{ha}^{-1}+900 \mathrm{~g}$ ae $\left.\mathrm{ha}^{-1}\right)$, each of which was applied to GR common ragweed at two stages based on the extended $\mathrm{BBCH}$ scale for dicotyledonous weed species (Hess et al. 1997). Rates of glyphosate, 2,4-D, and dicamba were selected to reflect the ratio and maximum allowed rate for their respective herbicidetolerant cropping systems (Anonymous 2014, 2016), while maintaining the factorial structure of the experimental design.

Herbicides were applied at (1) male flower bud appearance (BBCH 51) and (2) early female flowering (BBCH 61 to 63,10 to $30 \%$ of female flowers open; Figure 1). On average, GR common ragweed plants reached these growth stages at 28 and $43 \mathrm{~d}$ after planting (DAP), respectively. For context, soybean maturity groups representing the range of those grown across the United States and Canada (i.e., MG 00 to VIII) reach the R1 stage of development between 28 and 50 DAP (Boote 1981; Van Acker et al. 1993; Zhang et al. 2004). Based on the labels currently available for Xtend ${ }^{\mathrm{TM}}$ and Enlist ${ }^{\text {TM }}$ technologies, these glyphosate-phenoxy tank mixes should be applied no later than the R1 and R2 stages of soybean development, respectively (Anonymous 2015, 2016). Thus, it can be 

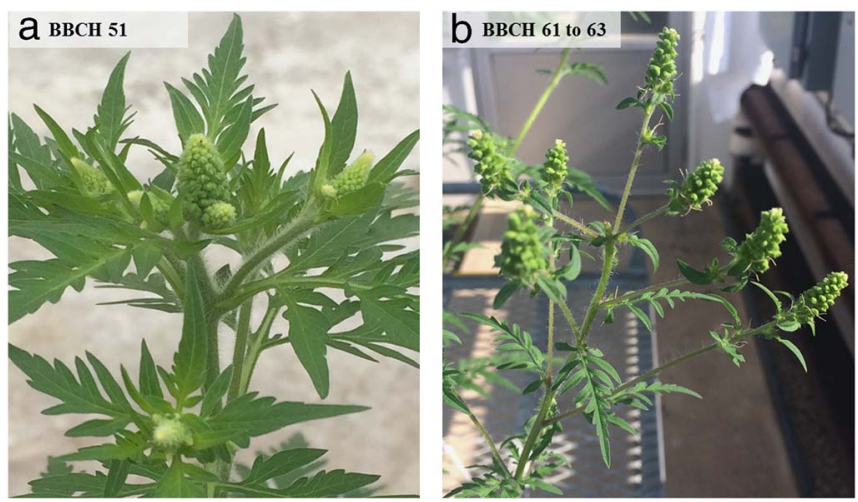

Figure 1. Common ragweed stage of development at the time of herbicide application: (a) BBCH 51 (male flower buds appearance) and (b) $\mathrm{BBCH} 61$ to 63 (early female flowering: $10-30 \%$ of female flowers open). The extended $\mathrm{BBCH}$ (Biologische Bundesanstalt, Bundessortenamt and Chemical industry) scale for dicotyledonous weed species was used (Hess et al. 1997).

conservatively stated that the herbicide application timings evaluated in the current study approximate the latest labeled timing for these new technologies and a late, off-label application timing (i.e., $\mathrm{BBCH}$ 51 and 61 to 63 , respectively).

Seed Collection and Preparation. Common ragweed involucral achenes (hereafter referred to as "seeds") of GR biotype were collected from a farm in Essex County, Ontario, Canada $\left(42.28^{\circ} \mathrm{N}\right.$, $82.84^{\circ} \mathrm{W}$; Van Wely et al. 2015) in September 2013. The seeds were stored dry in a controlledenvironment room (5 $\mathrm{C}$ and 50\% relative humidity $[\mathrm{RH}])$ until the commencement of the experiment.

Common ragweed seed possess Type 2 non-deep physiological dormancy (i.e., dormancy due to exogenous characteristics caused by a physiological mechanism of the embryo that inhibits the emergence of the radicle; Baskin and Baskin 2004, 2014; Finch-Savage and Leubner-Metzger 2006). Therefore, seeds were initially cold stratified to relieve dormancy and facilitate germination. In preparation for stratification, 200 seeds were placed in a petri dish lined with blue blotter paper (i.e., steel-blue germination blotters, Anchor Paper, St. Paul, MN) and moistened with $10 \mathrm{ml}$ of reverse-osmosis (RO) water. Petri dishes were then placed within a light-tight aluminum canister and refrigerated at $4 \mathrm{C}$ for $6 \mathrm{wk}$. Following stratification, seeds were transferred to new petri dishes $(25$ seeds dish $^{-1}$ ) containing blue blotter paper moistened with $10 \mathrm{ml}$ of $\mathrm{RO}$ water. These dishes were then placed into a seed germination cabinet (model G1000,
Conviron, Controlled Environment, Canada, Winnipeg, Manitoba, Canada) with a photoperiod of $14 \mathrm{~h}, 60 \% \mathrm{RH}$, and an alternating temperature of 25/15 C (day/night).

Plant Propagation. Germinated seeds of GR common ragweed were planted one to a cell in 24-cell plug flats $(6.4 \mathrm{~cm}$ cell top diameter and $6 \mathrm{~cm}$ cell depth) filled with high-porosity potting media (BM6, Berger, Saint Modest, Québec, Canada). Trays were placed into a growth chamber (model PGC20, Conviron, Controlled Environment, Winnipeg, Manitoba, Canada) with a photoperiod of $14 \mathrm{~h}, 80 \% \mathrm{RH}$, and an alternating thermoperiod of $25 / 20 \mathrm{C}$ (day/night). The seedlings were watered daily and fertilized weekly with a $1 \mathrm{~g} \mathrm{~L}^{-1}$ nutrient solution (Plant-Prod 20-20-20 N-P-K Classic, Master Plant-Prod, Brampton, Ontario, Canada).

Once seedlings reached the 3- to 4-leaf stage $(\mathrm{BBCH} 13)$, two plants were transplanted into each of 108 plastic pots $(16.5 \mathrm{~cm}$ diameter, $1.4 \mathrm{~L})$ filled with BM6 potting media. The pots were randomly assigned among three growth chambers (i.e., 36 pots in each replicate chamber) and maintained under the same conditions used for seedling growth. Although only 24 pots per replicate were required to conduct the experiment (see "Herbicide Application" section), 36 pots were initially created to ensure uniformity among the 24 pots selected. Two plants in each pot were thinned to one plant per pot at the 6- to 8-leaf stage. The pots were randomly rearranged within the chamber weekly to minimize position effects. The plants were watered daily except for the day of fertilization (once a week) with $2 \mathrm{~g} \mathrm{~L}^{-1}$ Plant-Prod ${ }^{\circledR}$ 20-20-20 N-P-K Classic.

Herbicide Application. Twenty-four plants of similar size within each growth chamber were selected and then randomly divided into two subgroups (i.e., BBCH 51 and $\mathrm{BBCH} 61$ to 63) containing 12 plants each. The two plants in each cabinet receiving the same treatment combination (i.e., herbicide by growth stage) were considered subsamples. Once they reached the corresponding stage of development (Figure 1), the plants were randomly assigned to one of six herbicide treatments. Herbicides were applied to the plants using an automated spray chamber equipped with $8002 \mathrm{E}$ even-spray nozzles set to apply at a rate of 333.3 $\mathrm{L} \mathrm{ha}^{-1}$ pressurized by $\mathrm{CO}_{2}$. Following herbicide application, plants were placed on separate benches in a greenhouse compartment to minimize the opportunity for herbicide transfer between

Bae et al.: Late herbicide application . 
treatments. The environmental conditions in the greenhouse were similar to those established in the growth chambers (described earlier). After $24 \mathrm{~h}$, the plants were returned to their assigned growth chambers. It is important to note that plants from all treatment combinations (i.e., herbicide by growth stage) were present in all three replicate growth chambers, and we did not attempt to control for pollen transfer among treatments. As a result, pollen from the untreated control could have, in theory, pollinated plants receiving herbicide applications, thus overriding any negative effects of pollen limitation on the fecundity of these treatments. Because common ragweed is a highly outcrossing species (Friedman and Barrett 2008), we chose to avoid biasing our measure of fecundity by restricting pollination to selfing. Moreover, previous research into the effects of herbicide application on pollination biology has demonstrated that glyphosate, 2,4-D, and dicamba have limited or a transitory influence on pollen production and viability but notable, detrimental impacts on the development of female flower organs (Amer and Ali 1974; Pepper et al. 1970; Pline et al. 2003). During the course of our experiment, we observed that common ragweed plants had a long duration of pollen shed (approximately 3 to $4 \mathrm{wk}$ ), and they continued producing male flowers on secondary branches even after herbicide application. We therefore conclude that the supply of pollen was not likely a confounding effect on ragweed fecundity; rather, the effect of herbicides on female flower development and receptivity was a more probable cause for the observed reductions in seed production.

\section{Growth and Reproductive Parameter Measure-}

ment. When seeds on test plants began to dry and ripen, causing a shift in color to brown, a fine-mesh $(0.1 \mathrm{~mm})$ polyester bag was wrapped around each plant and tied at the base to ensure all seeds produced were collected. Each plant was cut at the soil surface approximately $90 \mathrm{DAP}$ and placed into an individual paper bag. The samples were dried at 40 $\mathrm{C}$ for $1 \mathrm{wk}$. Aboveground dry biomass was determined by subtracting seed weight from total aboveground weight. Seeds were separated manually from the rest of the plant, and chaff and debris were removed using a seed blower (Model 757 South Dakota Seed Blower, Seedburo Equipment, Des Plaines, IL). Seeds were then counted by an electronic seed counter (Model ESC-1, Agriculex, Guelph, Ontario, Canada) and a 100-seed weight was estimated. Seeds were placed into paper envelopes and stored in the dark at $5 \mathrm{C}$ and 50\% $\mathrm{RH}$ until seed viability tests were initiated.

Seeds collected from the two plants in each cabinet receiving the same treatment combination (i.e., herbicide type by growth stage) were pooled. Then, 120 seeds per replicate of each treatment combination were surface sterilized with 5.5\% sodium hypochlorite solution for $5 \mathrm{~min}$ and subsequently rinsed with running $\mathrm{RO}$ water for $10 \mathrm{~min}$. Seeds were cold stratified for $6 \mathrm{wk}$ (as described earlier in "Seed Collection and Preparation"). Following the stratification period, 120 seeds were assigned to one of four petri dishes lined with blue blotter paper moistened with $10 \mathrm{ml}$ of $\mathrm{RO}$ water. Petri dishes were randomly assigned, by replicate, to a separate shelf of the germination cabinet under the same germination conditions as used previously (see "Seed Collection and Preparation"). The number of germinated seeds in each dish was recorded daily for a $21 \mathrm{~d}$ period, with all germinated seeds removed daily. Germination was defined by the presence of a radicle that was at least $2 \mathrm{~mm}$ in length. Seeds that had not germinated after the $21 \mathrm{~d}$ period were subjected to an initial pressure test with forceps, and those that did not resist the slight pressure were considered nonviable. The viability of all remaining seeds was determined using the tetrazolium chloride test (Peters 2000). The germination and viability tests were repeated twice.

Statistical Analysis. All analyses were performed using R software (v. 3.1.2; R Core Team 2015). To analyze the effect of herbicide treatment and growth stage on biomass, seed number, 100-seed weight, and seed viability, linear mixed-effects models were fit using the lmer function of the lme4 package (Bates et al. 2015). The fixed effects were herbicide treatment and growth stage. Intercepts for block and trial run were considered random effects. The two plants in each cabinet receiving the same treatment combination (i.e., herbicide by growth stage) were considered subsamples and, as such, were averaged for statistical analyses of biomass, seed number, and 100-seed weight. Percentages of control in biomass, seed number, and 100-seed weight were calculated and were analyzed. These data were transformed prior to the analysis as follows: aboveground biomass and seed weight ( $\log _{10}$ transformation); seed number (square-root transformation); and percentage of control and seed viability (arcsine square-root transformation). Back-transformed means are presented in tables and figures based on 
the interpretation from the transformed data. P-values were obtained by likelihood ratio tests of the full model with the effect in question against the model without the effect in question. Mean separations were conducted with the glht function of the multcomp package (Hothorn et al. 2008).

\section{Results and Discussion}

The total aboveground biomass of GR common ragweed at physiological maturity was influenced by the main effects of herbicide treatment and growth stage but not their interaction (Table 1). When herbicide treatments were applied at $\mathrm{BBCH} 51$, biomass accumulation at maturity was $22 \%$ lower than when herbicides were applied at $\mathrm{BBCH} 61$ to 63 (Table 2A). The application of 2,4-D alone or in a tank mix with glyphosate resulted in a statistically significant reduction in biomass relative to the control (Table 2A). As expected, the application of glyphosate to the GR biotype did not result in a reduction in total aboveground biomass at maturity. Although the exact mechanism conferring resistance to glyphosate in the tested biotype is not known, the resistance mechanism likely protects biomass production at flowering stages.

The main effects of herbicide treatment and growth stage influenced the 100-seed weight of GR common ragweed, but the interaction of these factors was not significant (Table 1). When herbicides were applied at $\mathrm{BBCH} 51$, the 100-seed weight of seeds produced at maturity was $16 \%$ greater than when herbicides were applied at $\mathrm{BBCH} 61$ to 63 (Table 2B). When glyphosate or 2,4-D was applied alone, there was no significant reduction in the 100 -seed weight relative to the control (Table 2B). Although dicamba applied alone did result in a significant reduction in the 100 -seed weight, the biological magnitude of this reduction was similar to that observed for 2,4-D (Table 2B). The largest reduction in 100-seed weight was observed when 2,4-D or dicamba were applied in a tank mix with glyphosate, with an average decline of $35 \%$ relative to the control.

Seed production in GR common ragweed was influenced by herbicide treatment, growth stage, and their interaction (Table 1). Compared with the control, applications of 2,4-D, dicamba, or dicamba plus glyphosate at $\mathrm{BBCH} 51$ provided greater than $80 \%$ reduction in seed production (Figure 2). At $\mathrm{BBCH}$ 61 to 63, all herbicide treatments, including glyphosate alone, reduced seed production relative to the control; however, this reduction was notably lower on average than that observed at $\mathrm{BBCH} 51$ (i.e., $-70 \%$ at $\mathrm{BBCH} 51$ vs. $-45 \%$ at $\mathrm{BBCH} 61$ to 63$)$. Overall, seed production following the application of glyphosate-phenoxy tank mixes was similar to that observed following the application of phenoxy herbicides alone, regardless of growth stage (Figure 2).

The viability of the seeds produced by GR common ragweed was influenced by herbicide treatment,

Table 1. Effect of the herbicide treatment, growth stage, or their interaction on (A) original data and (B) data expressed as a percent of control for dry biomass, 100-seed weight, seed production, and seed viability of glyphosate-resistant common ragweed.

\begin{tabular}{|c|c|c|c|c|}
\hline \multicolumn{5}{|l|}{ A. Raw data } \\
\hline & \multicolumn{4}{|c|}{$\chi^{2 \mathrm{a}}$} \\
\hline Growth stage & $34.72^{* * *}$ & $34.96^{* * *}$ & $4.23^{*}$ & $49.17^{* * *}$ \\
\hline Herbicide $\times$ growth stage & 5.81 & 7.47 & $23.96^{* * *}$ & $19.79^{* *}$ \\
\hline \multirow[t]{2}{*}{ Variable } & Dry biomass & 100-seed weight & Seed production & \\
\hline & & $\chi^{2}$ & & \\
\hline Herbicide & $31.33^{* * *}$ & $38.59^{* * *}$ & $41.16^{* * *}$ & \\
\hline Growth stage & $15.61^{* * *}$ & $11.74^{* * *}$ & $11.83^{* * *}$ & \\
\hline Herbicide $\times$ growth stage & 5.33 & 5.46 & $24.27^{* * *}$ & \\
\hline
\end{tabular}

\footnotetext{
${ }^{\text {a }}$ Significance of $\chi^{2}$ values was tested using P-values obtained by likelihood ratio tests of the full model with the effect in question against the model without the effect in question.

${ }^{*} \mathrm{p}<0.05$.

$* * \mathrm{p}<0.01$.

${ }^{* * *} \mathrm{p}<0.001$.
} 
Table 2. Means and percentage control of glyphosate-resistant common ragweed (A) dry biomass and (B) 100-seed weight in response to the herbicide treatments applied at the appearance of male flower buds (BBCH 51) or at the early female flowering (BBCH 61 to 63$).{ }^{a}$

A. Dry biomass

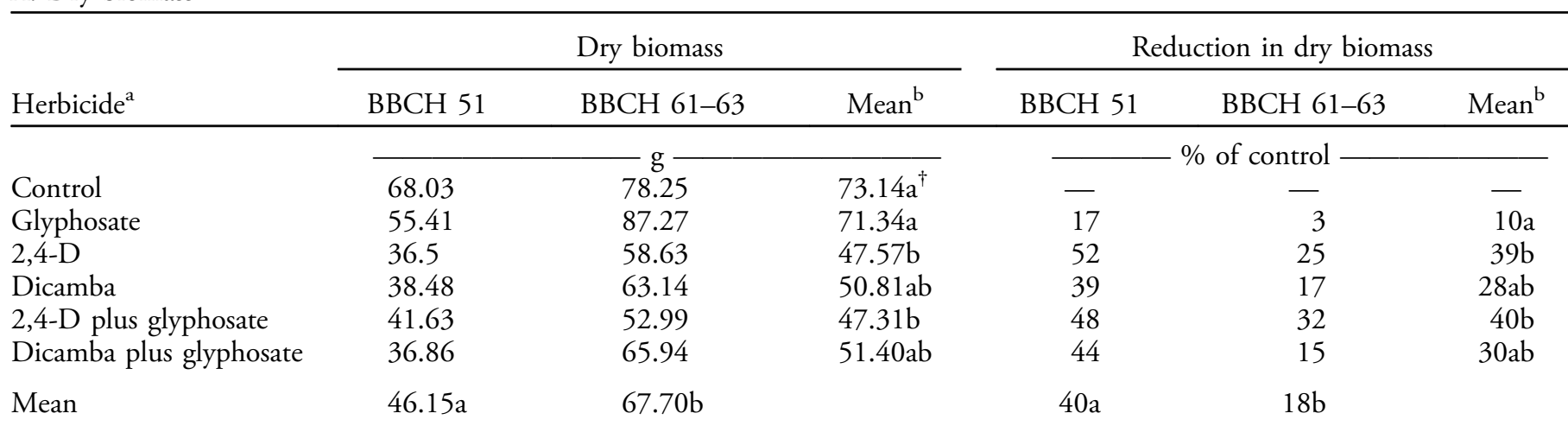

B. 100-seed weight

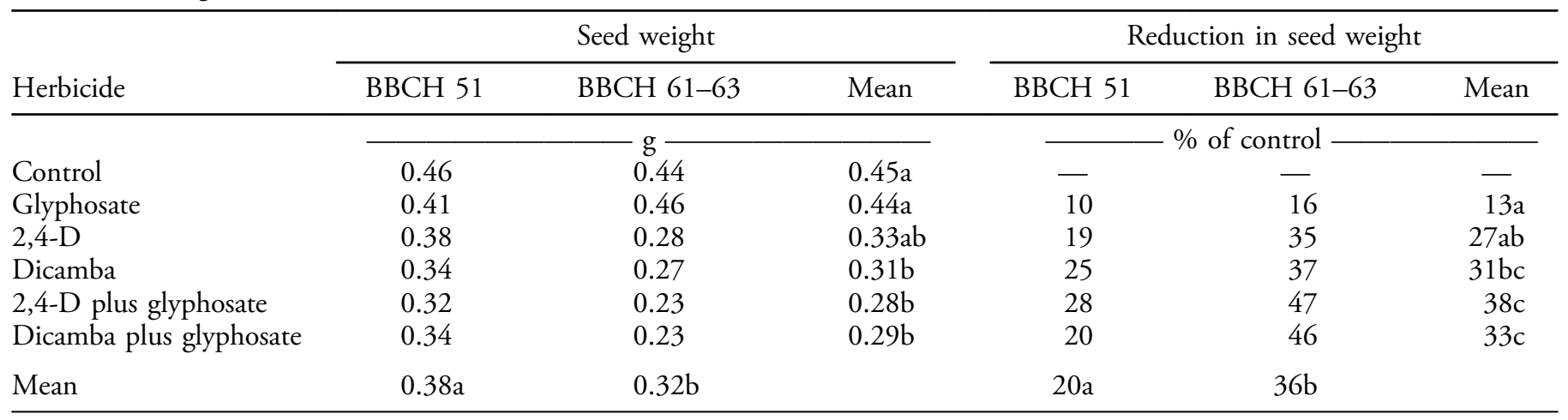

${ }^{\mathrm{a}}$ The herbicide treatments include: reverse-osmosis water control; glyphosate $\left(900 \mathrm{~g} \mathrm{ae} \mathrm{ha}^{-1}\right) ; 2,4-\mathrm{D}\left(733 \mathrm{~g}\right.$ ae ha $\left.{ }^{-1}\right)$; dicamba $(384 \mathrm{~g}$ ae ha $\left.{ }^{-1}\right)$; 2,4-D plus glyphosate $\left(733 \mathrm{~g} \mathrm{ae} \mathrm{ha}^{-1}\right.$ plus $\left.900 \mathrm{~g} \mathrm{ae} \mathrm{ha}^{-1}\right)$; and dicamba plus glyphosate $\left(384 \mathrm{~g} \mathrm{ae} \mathrm{ha}^{-1} \mathrm{plus}^{200 \mathrm{~g}^{2} \text { ae ha }}{ }^{-1}\right)$.

${ }^{\mathrm{b}}$ Means for main effects of herbicide and application timing within a data set sharing the same letters are not significantly different (Tukey's honest significant difference, $\alpha=0.05$ ).

growth stage, and their interaction (Table 1). At $\mathrm{BBCH} 51$, seed viability was similar among the herbicide treatments, with the exception of dicamba applied alone (Figure 3). In contrast, at BBCH 61 to 63, all herbicide treatments reduced seed viability relative to the control; however, treatments containing a Group 4 herbicide had significantly lower viability than when glyphosate was applied alone (Figure 3). As was the case with seed production, reductions in seed viability were similar when Group 4 herbicides were applied alone or in a tank mix with glyphosate, irrespective of growth stage at application.

Reducing the seed production of weed escapes is a central tenet of any proactive seedbank management strategy (Buhler et al. 1997; Davis 2006; Walsh et al. 2013). Targeting weed seed production becomes even more important when the weed escapes are known to occur as a result of herbicide resistance. In the case of GR common ragweed, seed production by escapes has the potential to create a large, long-lived seedbank that may contribute to the persistence and spread of this resistant biotype. Results of the present study demonstrate that the application of Group 4 herbicides has the potential to significantly reduce the seed production of GR common ragweed when applied at the appearance of male flower buds (Fig 1a). This result is in agreement with that of Jha and Norsworthy (2012), who observed that $2,4-\mathrm{D} \quad\left(1,060 \mathrm{gha}^{-1}\right)$ or dicamba $\left(280 \mathrm{~g} \mathrm{ha}^{-1}\right)$, each applied at the early inflorescence emergence stage, reduced seed production of GR Palmer amaranth by 75 to $95 \%$ and 84 to $95 \%$, respectively. Similarly, Fawcett and Slife (1978) and Taylor and Oliver (1997) reported that the application of 2,4-D or dicamba near flowering or bud formation effectively reduced seed production in common lambsquarters (Chenopodiumn album L.) and sicklepod [Senna obtusifolia (L.) H. S. Irwin \& Barneby], respectively. It is important to note, however, that the effectiveness of 2,4-D and dicamba at reducing seed production of GR

36 - Weed Science 65, January-February 2017 


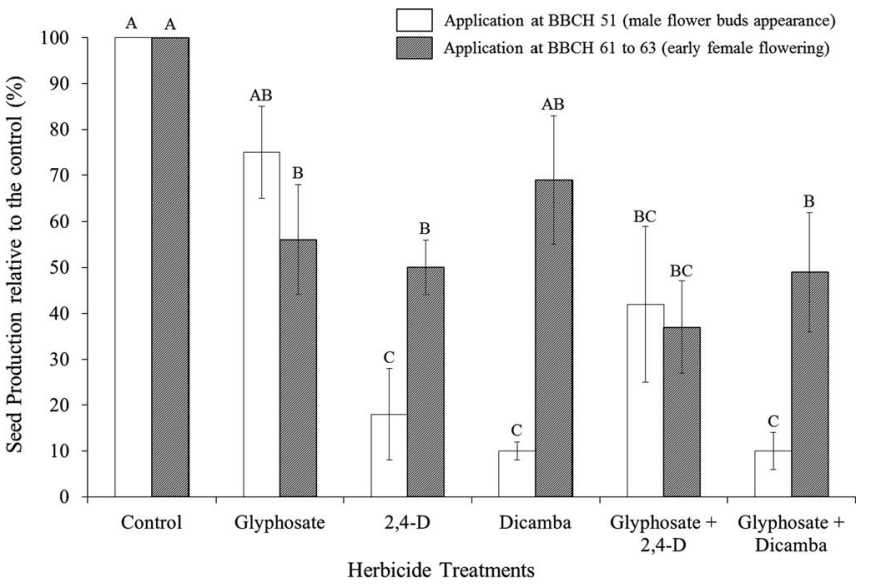

Figure 2. Glyphosate-resistant common ragweed seed production relative to the control in response to herbicide application at $\mathrm{BBCH} 51$ (male flower bud appearance) or at BBCH 61 to 63 (early female flowering). The extended $\mathrm{BBCH}$ (Biologische Bundesanstalt, Bundessortenamt and Chemical industry) scale for dicotyledonous weed species was used (Hess et al. 1997). The control plants produced $4719 \pm 656$ and $4005 \pm 1010$ seeds when treated with water at $\mathrm{BBCH} 51$ and $\mathrm{BBCH} 61$ to 63, respectively. Bars sharing the same letter indicate no significant difference (Tukey's honest significant difference, $\alpha=0.05$ ).

common ragweed was significantly reduced when these herbicides were applied $15 \mathrm{~d}$ later, when female flowers start to be receptive (Fig 1b). In fact, at this stage of development, there was no significant difference among 2,4-D, dicamba, and glyphosate in terms of their ability to influence the seed production of our GR common ragweed biotype.

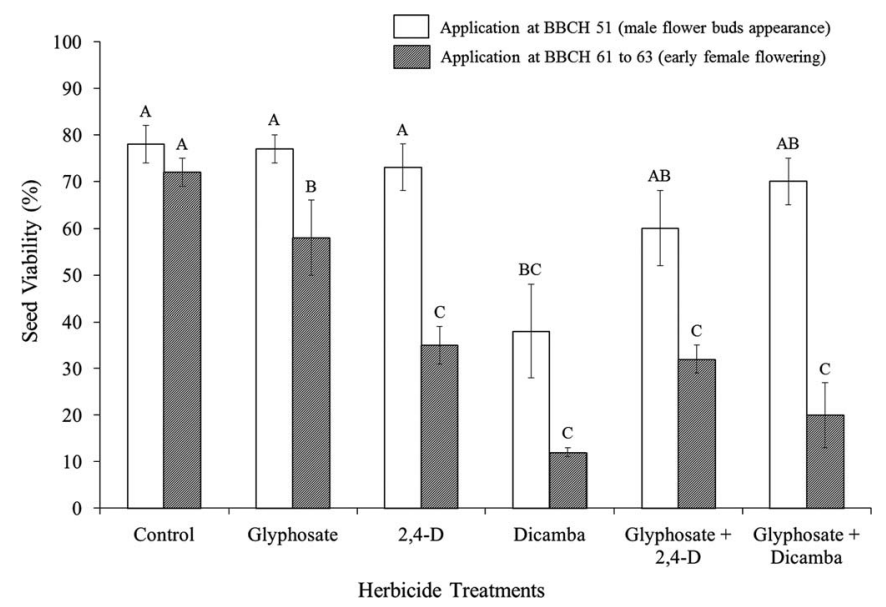

Figure 3. Seed viability of glyphosate-resistant common ragweed in response to herbicide application at BBCH 51 (male flower bud appearance) or at $\mathrm{BBCH} 61$ to 63 (early female flowering). The extended $\mathrm{BBCH}$ (Biologische Bundesanstalt, Bundessortenamt and Chemical industry) scale for dicotyledonous weed species was used (Hess et al. 1997). Bars sharing the same letter indicate no significant difference (Tukey's honest significant difference, $\alpha=0.05)$.
In general, seed viability and seed weight were reduced following the application of 2,4-D or dicamba during the reproductive stages of common ragweed development. Unsurprisingly, reductions in these traits were largest when treatments containing 2,4-D or dicamba were applied during the later stages of flowering (i.e., BBCH 61 to 63), when fertilized embryos may have been less likely to abort. Results from previous studies offer variable accounts of success in reducing weed seed viability following the application of 2,4-D or dicamba at developmental stages bracketing flowering (Fawcett and Slife 1978; Jha and Norsworthy 2012; Kumar and Jha 2015; McCarty and Hatting 1975; Taylor and Oliver 1997). For example, Taylor and Oliver (1997) reported that dicamba $\left(1,100\right.$ and 2,200 $\left.\mathrm{g} \mathrm{ha}^{-1}\right)$ applied at the early bud stage or the early flowering stage did not affect seed viability of sicklepod, whereas Jha and Norsworthy (2012) observed that dicamba $\left(280 \mathrm{~g} \mathrm{ha}^{-1}\right)$ applied at the first sign of inflorescence decreased seed viability of GR Palmer amaranth by $45 \%$. Much of this variation among studies can likely be attributed to small differences in the developmental stage at which the herbicide application was made, as the progression from vegetative to reproductive stages can sometime be quite rapid. In our experiment, for instance, the progression from $\mathrm{BBCH} 51$ to $\mathrm{BBCH} 61$ to 63 required on average $15 \mathrm{~d}$, however, individual common ragweed plants displayed considerable plant-to-plant variation in the time required to make this transition.

The developmental stages bracketing flowering are sensitive to biotic and abiotic stressors (Lauxmann et al. 2015; Morrison and Stewart 2002; Stephenson 1981; Tollenaar and Daynard 1978). Stressors encountered during these stages often result in flower or fruit abortion and in some cases reductions in fruit mass, depending on the severity or duration of the stress. While the application of herbicides during the stages bracketing flowering could elicit such responses simply via their activity as stressors of plant growth, the herbicides from Groups 4 and 9 used in the present study also translocate through the plant and accumulate in metabolic sinks, such as reproductive tissues (Duke et al. 2003; Senseman 2007; Sprankle et al. 1975; Wyrill and Burnside 1976). In particular, previous research has demonstrated that the application of glyphosate to susceptible species or biotypes during the stages bracketing flowering increases flower and fruit abortion and reduces the quality and viability of seed that may form (Clay and Griffin 2000; Gougler and Geiger 1981; Nurse et al. 2015; Steadman et al. 2006; Taylor and Oliver 1997; Walker and Oliver 2008). In a susceptible common 
ragweed biotype, for example, glyphosate $(540 \mathrm{~g}$ ae ha ${ }^{-1}$ ) applied at BBCH 53 to 55 (i.e., the bud appearance stage) and $\mathrm{BBCH} 61$ (flowering) completely inhibited seed production (Gauvrit and Chauvel 2010). In our study, glyphosate applied when male flower buds were present reduced neither seed number nor viability, whereas at the onset of female flowering, seed production was reduced by $45 \%$ and viability declined by $14 \%$, resulting in a net $48 \%$ reduction in viable seed production relative to the control. As was noted previously, all of the herbicides applied at BBCH 61 to 63, alone or in a tank mix, resulted in statistically similar reductions in seed production, indicating that this effect can most likely be attributed to the sensitivity of this growth stage to stressors rather than to the herbicidal activity of a specific chemical compound. However, while seed viability did decline following glyphosate application at $\mathrm{BBCH} 61$ to 63 , the reduction in viability was significantly less than when 2,4-D or dicamba was applied at the same growth stage (i.e., 14 vs. 47 and $60 \%$, respectively). The efficacy of $2,4-\mathrm{D}$ or dicamba at reducing common ragweed seed production and viability when applied at the growth stages examined in this study suggests that the herbicides were translocated to meristematic tissue, as would be expected in a Group 4-susceptible biotype. Conversely, the lack of reduction in seed production at $\mathrm{BBCH} 51$ and the slight decline in seed viability at BBCH 61 to 63 following glyphosate application suggest that altered absorption, translocation, or metabolism of glyphosate might restrict the movement of the herbicide into reproductive organs in this GR biotype. Previous studies have suggested both target-site and non-target site mechanisms for glyphosate resistance in common ragweed; however, a definitive consensus on the mechanism of resistance has yet to be reached (Brewer and Oliver 2009; Gaines et al. 2016; Parrish 2015).

Results from the current study add to our knowledge of the efficacy of 2,4-D or dicamba for the control of GR weed escapes. For GR common ragweed, 2,4-D or dicamba applied alone or in a tank mix with glyphosate could be effectively used to reduce seed production when applied at the onset of the flowering period. Providing that such late applications can be made with an acceptable level of crop safety, they may be an effective option for limiting seedbank replenishment, reducing population establishment, and preventing further spread of the resistant alleles. The recent development of crop hybrids and varieties with tolerance to Group 4 herbicides could facilitate grower adoption of targeted weed seed control strategies for GR biotypes. It should be emphasized, however, that in spite of the potential of a Group 4-tolerant cropping system for targeted control of GR escapes, the timing of the herbicide application relative to the developmental stage of the weed is of critical importance in determining the efficacy of the strategy with respect to seed production or viability.

\section{Acknowledgments}

The authors are grateful for the funding provided in support of this project by Agriculture and Agri-Food Canada (project \#J-00919). The authors would also like to acknowledge Dana Gagnier and Janet Blackburn for technical assistance and Peter Sikkema for reporting the original GR population.

\section{Literature Cited}

Amer SM, Ali EM (1974) Cytological effects of pesticides. Cytologia 39:633-643

Anonymous (2015) Enlist Duo ${ }^{\mathrm{TM}}$ product label. Calgary, AB, Canada: Dow AgroSciences Canada. $18 \mathrm{p}$

Anonymous (2016) Roundup Xtend ${ }^{\text {TM }}$ with VapourGrip ${ }^{\text {TM }}$ Technology herbicide product label. Winnipeg, MB Canada: Monsanto Canada. 22 p

Bazzaz FA (1974) Ecophysiology of Ambrosia artemisiifolia: a successional dominant. Ecology 55:112-119

Baskin CC, Baskin JM (2014) Seeds: Ecology, Biogeography, and Evolution of Dormancy and Germination. 2nd edn. New York: Elsevier. Pp 39-60

Baskin JM, Baskin CC (1980) Ecophysiology of secondary dormancy in seeds of Ambrosia artemisiifolia. Ecology 61:475-480

Baskin JM, Baskin CC (2004) A classification system for seed dormancy. Seed Sci Res 14:1-16

Bates D, Maechler M, Bolker B, Walker S (2015) Fitting linear mixed-effects models using lme4. J Stat Softw 67:1-48

Beckie HJ, Harker KN, Hall LM, Warwick SI, Légère A, Sikkema PH, Clayton GW, Thomas AG, Leeson JY, SéguinSwartz G, Simard MJ (2006) A decade of herbicide-resistant crops in Canada. Can J Plant Sci 86:1243-1264

Beckie HJ, Sikkema PH, Soltani N, Blackshaw RE, Johnson EN (2014) Environmental impact of glyphosate-resistant weeds in Canada. Weed Sci 62:385-392

Brewer CE, Oliver LR (2009) Confirmation and resistance mechanisms in glyphosate-resistant common ragweed (Ambrosia artemisiifolia) in Arkansas. Weed Sci 57:567-573

Bøhn T, Cuhra M, Traavik T, Sanden M, Fagan J, Primicerio R (2014) Compositional differences in soybeans on the market: glyphosate accumulates in Roundup Ready GM soybeans. Food Chem 153:207-215

Boote KJ (1981) Response of soybeans in different maturity groups to March plantings in southern USA. Agron J 73:854-859

Buhler DD, Hartzler RG, Forcella F (1997) Implications of weed seedbank dynamics to weed management. Weed Sci 45:329-336

38 - Weed Science 65, January-February 2017 
Clay PA, Griffin JL (2000) Weed seed production and seedling emergence responses to late-season glyphosate applications. Weed Sci 48:481-486

Coble HD, Williams FM, Ritter RL (1981) Common ragweed (Ambrosia artemisiifolia) interference in soybean (Glycine max). Weed Sci 29:339-342

Cowbrough MJ, Brown RB, Tardif FJ (2003) Impact of common ragweed (Ambrosia artemisiifolia) aggregation on economic thresholds in soybean. Weed Sci 51:947-954

Crow WD, Steckel LE, Hayes RM, Mueller TC (2015) Evaluation of POST-harvest herbicide applications for seed prevention of glyphosate-resistant Palmer amaranth (Amaranthus palmeri). Weed Technol 29:405-411

Davis AS (2006) When does it make sense to target the weed seed bank? Weed Sci 54:558-565

Dickerson CT Jr, Sweet RD (1971) Common ragweed ecotypes. Weed Sci 19:64-66

Duke SO, Rimando AM, Pace PF, Reddy KN, Smeda RJ (2003) Isoflavone, glyphosate, and aminomethylphosphonic acid levels in seeds of glyphosate-treated, glyphosate-resistant soybean. J Agr Food Chem 51:340-344

Fawcett RS, Slife FW (1978) Effects of 2,4-D and dalapon on weed seed production and dormancy. Weed Sci 26: 543-547

Finch-Savage WE, Leubner-Metzger G (2006) Seed dormancy and the control of germination. New Phytol 171:501-523

Friedman J, Barrett SCH (2008) High outcrossing in the annual colonizing species Ambrosia artemisiifolia (Asteraceae). Ann Bot 101:1303-1309

Gaine ZA, Juglum M, Varanasi VK, Jhala A (2016) Mechanisms of glyphosate resistance in common ragweed from Nebraska. Abstract 432 in Proceedings of 2016 WSSA/SWSS Annual Meeting. San Juan, Puerto Rico: Weed Science Society of America

Gauvrit C, Chauvel B (2010) Sensitivity of Ambrosia artemisiifolia to glufosinate and glyphosate at various developmental stages. Weed Res 50:503-510

Gougler JA, Geiger DR (1981) Uptake and distribution of $N$-phosphonomethylglycine in sugar beet plants. Plant Physiol 68:668-672

Heap I (2015) The International Survey of Herbicide Resistant Weeds. http://www.weedscience.org. Accessed August 2, 2015

Hess M, Barralis G, Bleiholder H, Buhr L, Eggers TH, Hack H, Stauss R (1997) Use of the extended BBCH scale-general for the descriptions of the growth stages of mono; and dicotyledonous weed species. Weed Res 37:433-441

Hill EC, Renner KA, VanGessel MJ, Bellinder RR, Scott BA (2016) Late-season weed management to stop viable weed seed production. Weed Sci 64:112-118

Hothorn T, Bretz F, Westfall P (2008) Simultaneous inference in general parametric models. Biometrical J 50:346-363

Jha P, Norsworthy JK (2012) Influence of late-season herbicide applications on control, fecundity, and progeny fitness of glyphosate-resistant Palmer amaranth (Amaranthus palmeri) biotypes from Arkansas. Weed Technol 26:807-812

Kumar V, Jha P (2015) Influence of herbicides applied postharvest in wheat stubble on control, fecundity, and progeny fitness of Kochia scoparia in the US Great Plains. Crop Prot 71:144-149

Lauxmann MA, Annunziata MG, Brunoud G, Wahl V, Koczut A, Burgos A, Olas JJ, Maximova E, Abel C, Schlereth A, Soja AM, Bläsing OE, Lunn JE, Vernoux T, Stitt M (2015)
Reproductive failure in Arabidopsis thaliana under transient carbohydrate limitation: flowers and very young siliques are jettisoned and the meristem is maintained to allow successful resumption of reproductive growth. Plant Cell Environ 39:745-767

McCarty MK, Hatting JL (1975) Effects of herbicides or mowing on musk thistle seed production. Weed Res 15:363-367

Morrison MJ, Stewart DW (2002) Heat stress during flowering in summer Brassica. Crop Sci 42:797-803

Nurse RE, Darbyshire SJ, Simard M-J (2015) Impact of post-anthesis glyphosate on woolly cupgrass seed production, seed weight and seed viability. Can J Plant Sci 95: 1193-1197

[OMAFRA] Ontario Ministry of Agriculture, Food and Rural Affairs (2009) Agronomy Guide for Field Crops. Publication 811. http://www.omafra.gov.on.ca/english/crops/pub811/ p811 toc.html. Accessed: July 28, 2015

[OMAFRA] Ontario Ministry of Agriculture, Food and Rural Affairs (2015) Guide to Weed Control. Publication 75. http:// www.omafra.gov.on.ca/english/crops/pub75/pub75toc.htm. Accessed May 4, 2016

Parrish JT (2015) Investigations into Multiple-HerbicideResistant Ambrosia artemisiifolia (Common Ragweed) in Ohio and Glyphosate-Resistance Mechanisms. Ph.D. dissertation. Columbus, OH: Ohio State University. $128 \mathrm{p}$

Payne KK, Sleugh BB, Bradley KW (2010) Impact of herbicides and application timing on weed control, yield, and nutritive value of tall fescue pastures and hayfields. Weed Technol 24:515-522

Pepper TF, Weibel DE, Santelmann PW (1970) Influence of dicamba on the growth and development of grain sorghum. Agron J 62:407-411

Peters J, ed (2000) Tetrazolium Testing Handbook. Las Cruces, NM: Association of Official Seed Analysis Contribution No. 29

Pline WA, Edmisten KL, Wilcut JW, Wells R, Thomas J (2003) Glyphosate-induced reductions in pollen viability and seed set in glyphosate-resistant cotton and attempted remediation by gibberellic acid (GA3). Weed Sci 51:19-27

$\mathrm{R}$ Core Team (2015) R: a language and environment for statistical computing. Vienna, Austria: R Foundation for Statistical Computing. https://www.R-project.org

Senseman SA, ed (2007) Herbicide Handbook. 9th edn. Champaign, IL: Weed Science Society of America. 458 p

Shurtleff JL, Coble HD (1985) Interference of certain broadleaf weed species in soybeans (Glycine max). Weed Sci 33:654-657

Simard M-J, Benoit DL (2012) Potential pollen and seed production from early- and late-emerging common ragweed in corn and soybean. Weed Technol 26:510-516

[SCCC] Soil Conservation Council of Canada (2015) Reduced Tillage Helps Reduce Carbon Dioxide Levels. http://www. soilcc.ca/ggmp_feature_articles/2004/2004-02.php. Accessed August 2, 2015

Sprankle P, Meggitt WF, Penner D (1975) Absorption, action, and translocation of glyphosate. Weed Sci 23: $235-240$

Steadman KJ, Eaton DM, Plummer JA, Ferris DG, Powles SB (2006) Late-season non-selective herbicide application reduces Lolium rigidum seed numbers, seed viability, and seedling fitness. Aust J Agric Res 57:133-141

Stephenson AG (1981) Flower and fruit abortion: proximate causes and ultimate functions. Annu Rev Ecol Syst 12: 253-279 
Taylor SE, Oliver LR (1997) Sicklepod (Senna obtusifolia) seed production and viability as influenced by late-season postemergence herbicide applications. Weed Sci 45:497-501

Tollenaar M, Daynard TB (1978) Effect of defoliation on kernel development in maize. Can J Plant Sci 58:207-212

Van Acker RC, Swanton CJ, Weise SF (1993) The critical period of weed control in soybean [Glycine $\max$ (L.) Merr.]. Weed Sci 41:194-200

Van Wely AC, Soltani N, Robinson DE, Hooker DC, Lawton MB, Sikkema PH (2015) Glyphosate and acetolactate synthase inhibitor resistant common ragweed (Ambrosia artemisiifolia L.) in southwestern Ontario. Can J Plant Sci 95:335-338

Wade T, Claassen R, Wallander S (2015) Conservation-practice adoption rates vary widely by crop and region. Washington, DC: U.S. Department of Agriculture, Economic Research Service EIB-147. http://www.ers.usda.gov/publications/eibeconomic-information-bulletin/eib147. Accessed April 26, 2016

Walker ER, Oliver LR (2008) Translocation and absorption of glyphosate in flowering sicklepod (Senna obtusifolia). Weed Sci 56:338-343
Walsh M, Newman P, Powles S (2013) Targeting weed seeds in crop: a new weed control paradigm for global agriculture. Weed Technol 27:431-436

Weaver SE (2001) Impact of lamb's-quarters, common ragweed and green foxtail on yield of corn and soybean in Ontario. Can J Plant Sci 81:821-828

Wyrill JB, Burnside OC (1976) Absorption, translocation, and metabolism of 2,4-D and glyphosate in common milkweed and hemp dogbane. Weed Sci 24:557-566

Young BG (2006) Changes in herbicide use patterns and production practices resulting from glyphosate-resistant crops. Weed Technol 20:301-307

Zhang L, Zhang J, Watson CE, Kyei-Boahen S (2004) Developing phenological prediction tables for soybean. Crop Manage 3 (doi: 10.1094/CM-2004-1025-01-RS)

Received June 7, 2016, and approved September 9, 2016.

Associate Editor for this paper: J. Anita Dille, Kansas State University. 